
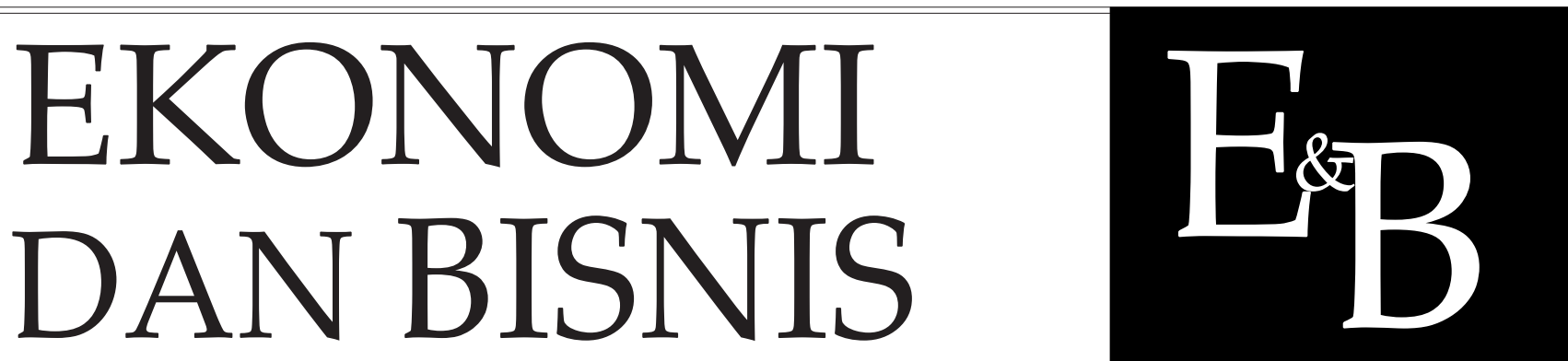

Berkala Publikasi Gagasan Konseptual, Hasil Penelitian, Kajian, dan Terapan Teori

Sugeng Hariadi

Sari Angriani

Dwi Ayu Sekarini Putri

Firman Rosjadi

Made Siti Sundari

Jefri Thomi da Costa Boreel

Mintarti Ariani

Bambang Budiarto

Nita Lintang Sekarrini

Siti Rahayu

Rahmat Setiawan

Koko Sudiro
DAYA SAING EKSPOR DAN PERKEMBANGAN PANGSA PASAR IKAN TUNA INDONESIA DI PASAR INTERNASIONAL PERIODE 2012-2016

ANALISIS KINERJA KEUANGAN BANK UMUM KONVENSIONAL DENGAN ASET TERENDAH DI INDONESIA PERIODE 2014-2017

PENGARUH EXPERIENTIAL VALUE DAN PLACE FOOD IMAGE YOGYAKARTA TERHADAP BEHAVIORAL INTENTIONS WISATAWAN DOMESTIK

STRUK TUR MODAL DAN PROFITABILITAS PERUSAHAAN ANGGOTA HOLDING PT PUPUK INDONESIA (PERSERO) 


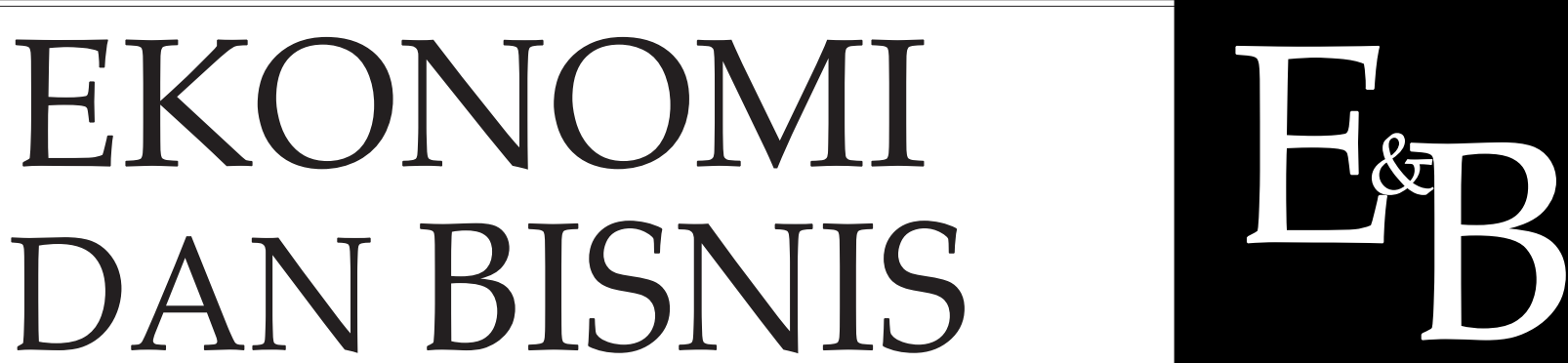

Berkala Publikasi Gagasan Konseptual, Hasil Penelitian, Kajian, dan Terapan Teori

Sugeng Hariadi, Sari Angriani :

PENGARUH PERSEPSI KEYAKINAN DAN BAGI HASIL TERHADAP MINAT

MENABUNG DI BANK SYARIAH

Dwi Ayu Sekarini Putri, Firman Rosjadi, Made Siti Sundari :

DAYA SAING EKSPOR DAN PERKEMBANGAN PANGSA PASAR IKAN

TUNA INDONESIA DI PASAR INTERNASIONAL PERIODE 2012-2016

Jefri Thomi da Costa Boreel, Mintarti Ariani, Bambang Budiarto :

ANALISIS KINERJA KEUANGAN BANK UMUM KONVENSIONAL

DENGAN ASET TERENDAH DI INDONESIA PERIODE 2014-2017

Nita Lintang Sekarrini, Siti Rahayu :

PENGARUH EXPERIENTIAL VALUE DAN PLACE FOOD IMAGE

YOGYAKARTA TERHADAP BEHAVIORAL INTENTIONS WISATAWAN

DOMESTIK

Rahmat Setiawan, Koko Sudiro :

STRUKTUR MODAL DAN PROFITABILITAS PERUSAHAAN ANGGOTA HOLDING PT PUPUK INDONESIA (PERSERO) 



\title{
PENGARUH PERSEPSI KEYAKINAN DAN BAGI HASIL TERHADAP MINAT MENABUNG DI BANK SYARIAH \\ Sugeng Hariadi \\ Sari Angriani
}

Jurusan Ilmu Ekonomi, Fakultas Bisnis dan Ekonomika, Universitas Surabaya ssihar@gmail.com

\begin{abstract}
Islamic Banking is a banking institution that runs with the principles of sharia. In every business activity, Islamic banks always use the laws of Islam listed in the Qur'an and Hadith. This study aims to determine the influence of perceptions of beliefs, and profit sharing perceptions of interest in saving. This research is a quantitative descriptive research with survey method. The population in this study are Surabaya students who are saving in Bank Sharia. Instrument test, classical assumption test, and data analysis test in this study using SPSS. From the results of the study, it is known that the perception of belief has a positive and significant effect to the interest of saving, and the perception of the results have a positive and significant impact on interest in saving.
\end{abstract}

Keywords: Islamic Banking, belief, profit sharing

\section{PENDAHULUAN}

Praktik perbankan Islam di Indonesia dimulai pada akhir 1980-an yang dimulai dengan lahirnya bank syariah pertama di Indonesia yaitu Bank Muamalat pada 1992 (Rianto, 2011). Bank Syariah adalah bank yang beroperasi dengan prinsip syariah, yaitu aturan perjanjian berdasarkan hukum Islam antara bank dan pihak lain dalam penyimpanan dana dan atau pembiayaan kegiatan usaha. Bank Syariah diatur secara formal sejak diamandemennya UU No.7 Tahun 1992 dengan UU No.10 Tahun 1998 dan UU No.23 Tahun 1999 (Mangani, 2009).

Menurut penelitian yang dilakukan Woldie dalam Wibowo (2008), terungkap faktor-faktor alasan pelanggan bermitra dengan bank syari'ah. Setelah dirangking maka urutan motivasi bermitra dengan bank syari'ah adalah pertama faktor keagamaan, kedua kepercayaan terhadap terhadap komite pengawasan dalam bank syari'ah, ketiga kerahasiaan, keempat reputasi dan citra, dan kelima sifat sosial dan ramah dari pegawai bank.

Bank Syariah memiliki tiga segmentasi pasar berdasarkan usia nasabah, tentunya untuk melakukan pengembangan Bank Syariah harus memperhatikan tiga segmentasi pasar ini. Berdasarkan riset MARS Indonesia (Gambar 1), persentase terbesar nasabah perbankan syariah ada di kelompok usia tua (35-55 tahun), yaitu 
mencapai 50,8\%. Berikutnya ada di kelompok usia dewasa (25-34 tahun) sebesar $37,6 \%$ dan di kelompok usia muda (18-24 tahun) sebesar 11,6\%.

Objek penelitian ini adalah kelompok umur 18-24 tahun. Range umur tersebut memiliki persentase paling rendah dari tiga segmentasi yang ada. Nasabah masih berstatus mahasiswa aktif. Memiliki minat untuk menabung di Bank Syariah namun masih beranggapan bahwa ada kesamaan antara Bank Syariah dan bank konvensional.
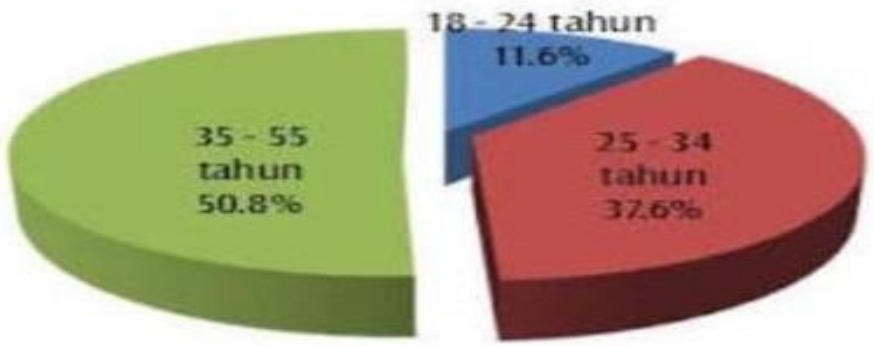

Sumber MARS Indonesia 2011

\section{Gambar 1: Profil Nasabah Bank Syariah Berdasarkan Usia}

Surabaya adalah salah satu kota yang menjadi tempat belajar mahasiswa dari berbagai daerah di Indonesia. Pilihan mahasiswa Surabaya sebagai responden penelitian karena untuk mengetahui seberapa besar minat mahasiswa Surabaya yang menabung dan menjadi nasabah dengan berlandaskan nilai-nilai keislaman, memuati pendidikan keislaman, yaitu Al-Qur'an, hadist, memasukkan nilai-nilai keislaman dalam kegiatan sehari-hari. Dengan demikian menarik untuk mengkaji lebih dalam perilaku menabung pada mahasiswa Surabaya.

Nasabah bank syariah memiliki alasan masing-masing dalam memilih bank syariah. Faktor-faktor tersebut antara lain keyakinan bahwa Islam berpandangan bahwa menetapkan bunga adalah riba yang berlipat ganda. Berikutnya adalah alasan bagi hasil, yakni tingkat keuntungan atau manfaat yang akan diperoleh dalam menggunakan suatu produk atau jasa.

\section{METODE PENELITIAN}

Jenis studi ini adalah kuantitatif asosiatif yaitu dengan menggunakan unit analisis yang diteliti adalah mahasiswa Surabaya. Studi asosiatif bertujuan untuk mengetahui hubungan antara dua variabel atau lebih (Sugiyono, 2005). Studi ini termasuk dalam penelitian survei, yakni data dan informasi didapat dari pengumpulan populasi (sampel). 
Dalam studi ini, populasi sasaran yang dimaksud adalah mahasiswa Surabaya dengan umur 19 tahun ke atas yang sudah memiliki KTP. Hal ini karena persyaratan membuka buku tabungan adalah KTP.

Dipilihnya populasi sasaran yaitu di Surabaya dalam penelitian ini dikarenakan mahasiswa Surabaya berasal dari berbagai daerah di Indonesia dari seluruh kalangan dan juga memiliki keyakinan berbeda-beda, rata-rata mahasiswa sudah memiliki tabungan yang digunakan untuk membayar uang kuliah, transfer, dan kegiatan transaksi lain.

Metode pengumpulan data yang digunakan yaitu dengan menggunakan kuesioner yang disebar secara online. Data berjenis ordinal yaitu berasal dari suatu objek atau kategori yang telah disusun secara berjenjang menurut besarnya, dengan menggunakan skala pengukuran nominal yaitu menggunakan skor 1 hingga skor 4 .

Menurut Kriyantono (2006), untuk beberapa riset, skala nominal dapat digunakan dengan meniadakan pilihan jawaban ragu-ragu. Hal ini karena kategori tersebut memiliki makna ganda yaitu bisa diartikan belum bisa memberikan jawaban, netral, dan ragu-ragu.

Uji coba instrumen menggunakan uji validitas dan reliabilitas untuk mengetahui apakah instrument yang digunakan sudah valid dan reliabel. Teknik analisis data ini menggunakan program SPSS 20.00 dan menggunakan metode analisis deskriptif. Hal ini bertujuan untuk mengetahui gambaran karakteristik responden dari jenis kelamin, pendidikan, dan nama bank yang digunakan.

Pengujian asumsi klasik mencakup uji multikolineritas, uji autokorelasi, dan uji heterokedastisitas, agar data yang diolah benar-benar dapat mewakili populasi secara keseluruhan. Analisis regresi berganda juga digunakan untuk mengukur besar pengaruh antara variabel persepsi keyakinan $\left(\mathrm{X}_{1}\right)$ dan persepsi bagi hasil $\left(\mathrm{X}_{2}\right)$ terhadap minat menabung di Bank Syariah (Y).

\section{HASIL DAN PEMBAHASAN}

Berdasarkan hasil penyebaran kuesioner, terdapat 92 total data yang dapat dianalisis. Tabel 1 menunjukkan bahwa dari 92 responden yang diteliti, sebanyak 26 responden atau $28,261 \%$ berjenis kelamin pria sedangkan responden yang berjenis kelamin wanita sebanyak 66 orang atau $71,739 \%$.

Tabel 1: Jenis Kelamin Responden

\begin{tabular}{|c|c|c|c|}
\hline No & Jenis Kelamin & Frekuensi & Persen (\%) \\
\hline 1 & Pria & 26 & $28,261 \%$ \\
\hline 2 & Wanita & 66 & $71,739 \%$ \\
\hline & Total & 92 & $100,0 \%$ \\
\hline
\end{tabular}

Sumber: Data yang diolah 
Selanjutnya, Tabel 2 menunjukkan bahwa dari 92 responden yang diteliti, beragama Islam sebanyak 89 orang atau 95,699\%, beragama Kristen 1 orang atau $1,075 \%$ dan sebanyak 3 orang atau 3,226\% beragama Katolik, selanjutnya responden beragama Hindu, Budha, dan Kong Hu Chu belum ada dengan nilai prsentase 0,000\%.

Tabel 2: Agama Responden

\begin{tabular}{|c|l|c|c|}
\hline No & Agama & Frekuensi & Persen (\%) \\
\hline $\mathbf{1}$ & Islam & 89 & $95,699 \%$ \\
\hline $\mathbf{2}$ & Kristen & 1 & $1,075 \%$ \\
\hline $\mathbf{3}$ & Katolik & 3 & $3,226 \%$ \\
\hline $\mathbf{4}$ & Hindu & 0 & $0,000 \%$ \\
\hline $\mathbf{5}$ & Budha & 0 & $0,000 \%$ \\
\hline $\mathbf{6}$ & Kong Hu Chu & 0 & $0,000 \%$ \\
\hline & Jumlah & 92 & $100,0 \%$ \\
\hline
\end{tabular}

Sumber: Data, diolah.

Sementara itu, Tabel 3 menunjukkan bahwa responden yang menabung di Bank Mandiri Syariah ada 32 orang atau 34,783\%, BCA Syariah ada 15 orangatau 16,304\%, BNI Syariah 24 orang atau 26,087\%, BRI Syariah 13 atau 14,130\%, Muamalat 7 orang atau 7,609\%, dan BTN Syariah 1 orang atau 1,08\%.

Tabel 3: Bank Responden

\begin{tabular}{|c|l|c|c|}
\hline No. & \multicolumn{1}{|c|}{ Bank } & Frekuensi & Persen (\%) \\
\hline 1 & Mandiri Syariah & 32 & $34,783 \%$ \\
\hline 2 & BCA Syariah & 15 & $16,304 \%$ \\
\hline 3 & BNI Syariah & 24 & $26,087 \%$ \\
\hline 4 & BRI Syariah & 13 & $14,130 \%$ \\
\hline 5 & Muamalat & 7 & $7,609 \%$ \\
\hline 6 & BTN Syariah & 1 & $1,087 \%$ \\
\hline & Jumlah & 92 & $100,0 \%$ \\
\hline
\end{tabular}

Sumber: Data yang diolah.

Akhirnya, berdasarkan Tabel 4, maka persamaan garis regresi dapat dinyatakan dalam persamaan berikut.

$$
\begin{gathered}
Y=\alpha+\beta_{1} X_{1}+\beta_{2} X_{2}+\varepsilon \\
Y=5,374+0,394 X_{1}+0,357 X_{2}+\varepsilon
\end{gathered}
$$

Nilai variabel dependen Minat Membeli (Y) dapat dilihat dari nilai konstanta sebesar 5,374 dengan catatan jika variable independen Persepsi Keyakinan $\left(\mathrm{X}_{1}\right)$ dan Persepsi Bagi Hasil $\left(\mathrm{X}_{2}\right)$ tidak mempengaruhi variable dependen Minat Menabung $\left(\mathrm{Y}_{1}\right)$. 


\section{Tabel 4: Hasil Perhitungan Regresi Linier Berganda Coefficients $^{a}$}

\begin{tabular}{|c|c|c|c|c|c|c|c|c|}
\hline & \multirow[t]{2}{*}{ Model } & \multicolumn{2}{|c|}{$\begin{array}{c}\text { Unstandardized } \\
\text { Coefficients }\end{array}$} & \multirow{2}{*}{$\begin{array}{c}\text { Standardized } \\
\text { Coefficients }\end{array}$} & \multirow[t]{2}{*}{$t$} & \multirow[t]{2}{*}{ Sig. } & \multicolumn{2}{|c|}{$\begin{array}{c}\text { Collinearity } \\
\text { Statistics }\end{array}$} \\
\hline & & B & Std. Error & & & & Tolerance & VIF \\
\hline \multirow{3}{*}{1} & (Constant) & 5,374 & 1,402 & & 3,833 & ,000 & & \\
\hline & $X_{1}$ &, 394 & ,093 & ,446 & 4,228 & ,000 &, 446 & 2,242 \\
\hline & $X_{2}$ & ,357 & ,107 & ,353 & 3,348 &, 001 & ,446 & 2,242 \\
\hline
\end{tabular}

a. Dependent Variable: $Y$

Sumber: Data yang diolah

Pengaruh variable independen Persepsi Keyakinan $\left(\mathrm{X}_{1}\right)$ terhadap Minat Menabung (Y) apabila dilihat dari besarnya koefisien regresi 0,394 maka dapat diartikan bahwa setiap perubahan variable Persepsi Keyakinan $\left(\mathrm{X}_{1}\right)$ sebesar satu satuan maka variable Minat Menabung (Y) akan meningkat sebesar sebesar 0,394 dengan catatan variable Persepsi Keyakinan $\left(\mathrm{X}_{1}\right)$ tetap.

Pengaruh variable independen Persepsi Bagi Hasil $\left(\mathrm{X}_{2}\right)$ terhadap Minat Menabung (Y) apabila dilihat dari besarnya koefisien regresi 0,357 maka dapat diartikan bahwa setiap perubahan variable Persepsi Bagi Hasil $\left(\mathrm{X}_{2}\right)$ sebesar satu satuan maka variable Minat Menabung (Y) akan meningkat sebesar sebesar 0,357 dengan catatan variable Minat Menabung (Y) dan tetap. Hal ini berarti arah model tersebut adalah positif.

Tabel 5: Hasil Perhitungan Koefisien Korelasi (R) dan Koefisien Determinasi $\left(\mathbf{R}^{2}\right)$

Model Summary ${ }^{b}$

\begin{tabular}{|l|r|r|r|r|r|}
\hline Model & $\mathrm{R}$ & $R$ Square & $\begin{array}{c}\text { Adjusted } R \\
\text { Square }\end{array}$ & $\begin{array}{l}\text { Std. Error of } \\
\text { the Estimate }\end{array}$ & $\begin{array}{l}\text { Durbin- } \\
\text { Watson }\end{array}$ \\
\hline 1 &, $747^{\mathrm{a}}$ &, 558 &, 548 & 1,46156 & 1,944 \\
\hline
\end{tabular}

a. Predictors: (Constant), $\mathrm{X}_{1}, \mathrm{X}_{2}$

b. Dependent Variable: $\mathrm{Y}$

Sumber: Data yang diolah.

Berdasarkan Tabel 5, diketahui bahwa nilai koefisien korelasi berganda (R), yaitu korelasi antara dua atau lebih variabel independen (Persepsi Keyakinan $\left(\mathrm{X}_{1}\right)$ dan Persepsi Bagi Hasil $\left(\mathrm{X}_{2}\right)$ terhadap variabel dependen (Minat Menabung $(\mathrm{Y})$ ) sebesar 0,558 . Hal ini berarti terdapat hubungan yang kuat. 
Nilai koefisien determinasi berganda (adjusted $R$-square) adalah 0,548 atau 54,8\%. Nilai ini menunjukkan bahwa 54,8\% Minat Menabung (Y) dipengaruhi oleh Persepsi Keyakinan $\left(\mathrm{X}_{1}\right)$ dan Persepsi Bagi Hasil $\left(\mathrm{X}_{2}\right)$, sedangkan sisanya 45,2\% dipengaruhi oleh variabel lain di luar penelitian.

\section{Tabel 6: Hasil Perhitungan Uji t}

\section{Coefficients $^{a}$}

\begin{tabular}{|c|c|c|c|c|c|c|c|}
\hline \multirow{2}{*}{ Model } & \multicolumn{2}{|c|}{$\begin{array}{c}\text { Unstandardized } \\
\text { Coefficients }\end{array}$} & \multirow{2}{*}{\begin{tabular}{|c}
$\begin{array}{c}\text { Standardized } \\
\text { Coefficients }\end{array}$ \\
Beta
\end{tabular}} & \multirow[b]{2}{*}{$t$} & \multirow[b]{2}{*}{ Sig. } & \multicolumn{2}{|c|}{$\begin{array}{c}\text { Collinearity } \\
\text { Statistics }\end{array}$} \\
\hline & $\mathrm{B}$ & Std. Error & & & & Tolerance & VIF \\
\hline (Constant) & 5,374 & 1,402 & & 3,833 & , 000 & & \\
\hline $\mathrm{X}_{1}$ & ,394 & ,093 & 446 & 4,228 & , 000 & 446 & 2,242 \\
\hline $\mathrm{X}_{2}$ &, 357 & , 107 & ,353 & 3,348 & ,001 & ,446 & 2,242 \\
\hline
\end{tabular}

a. Dependent Variable: $Y$

Sumber: Data diolah.

Persepsi Keyakinan $\left(\mathrm{X}_{1}\right)$ memperoleh nilai $\mathrm{T}$ hitung sebesar 4,228>1.9869 dan signifikansi $0,000<0,05$ maka hal ini menunjukkan bahwa secara parsial variabel Persepsi Keyakinan $\left(\mathrm{X}_{1}\right)$ berpengaruh signifikan terhadap Minat Menabung (Y).

Persepsi Bagi Hasil $\left(\mathrm{X}_{2}\right)$ memperoleh nilai T hitung sebesar 3,348>1.9869 dan signifikansi $0,001<0,05$ maka hal ini menunjukkan bahwa secara parsial variabel Persepsi Keyakinan $\left(\mathrm{X}_{1}\right)$ berpengaruh signifikan terhadap Minat Menabung (Y).

\section{Tabel 7: Hasil Perhitungan Uji F}

ANOVA $^{\mathrm{a}}$

\begin{tabular}{|c|c|c|c|c|c|}
\hline Model & Sum of Squares & $D f$ & Mean Square & $F$ & Sig. \\
\hline Regression & 681,378 & 2 & 340,689 & 56,226 &, $000^{\mathrm{b}}$ \\
\hline Residual & 539,275 & 89 & 6,059 & & \\
\hline Total & 1220,652 & 91 & & & \\
\hline
\end{tabular}

a. Dependent Variable: $\mathrm{Y}$

b. Predictors: (Constant), $\mathrm{X}_{1}, \mathrm{X}_{2}$

Sumber: Datayang diolah.

Nilai $\mathrm{F}$ hitung $>\mathrm{F}$ tabel, yaitu 56,226> 3.95 dan signifikansi $0,000<0,05$ menunjukkan bahwa Persepsi Keyakinan $\left(\mathrm{X}_{1}\right)$ dan Persepsi Bagi Hasil $\left(\mathrm{X}_{2}\right)$ secara serentak atau bersama sama berpengaruh terhadap Minat Menabung (Y).

Studi ini menemukan bahwa persepsi keyakinan berpengaruh positif dan signifikan terhadap minat menabung di Bank Syariah oleh mahasiswa Surabaya. Hal 
ini dapat dibuktikan dengan nilai t hitung parsial dengan memperoleh nilai t hitung lebih besar dari t tabel 4,228>1.9869 dan nilai signifikansi $0,000<0,05$.

Nilai koefisien determinasi berganda (adjusted $R$-square) adalah 0,548 atau $54,8 \%$. Nilai ini menunjukkan bahwa $54,8 \%$ berpengaruh positif terhadap minat menabung di Bank Syariah pada mahasiswa Surabaya.

Studi ini sesuai dengan penelitian yang dilakukan oleh Abdallah (2016) bahwa persepsi keyakinan berpengaruh positif dan signifikan terhadap minat menabung di Bank Syariah. Hasil studi ini mengkonfirmasi teori, bahwa persepsi keyakinan berpengaruh positif dan signifikan terhadap minat menabung di Bank Syariah.

Hal ini ini mengindikasikan bahwa persepsi keyakinan memberikan gambaran responden di dalam memilih jasa Bank Syariah dan menjadi pertimbangan paling dominan. Keyakinan bahwa bunga bank bertentangan dengan agama oleh mahasiswa Surabaya, telah mampu mempertahankan hubungan atau tetap loyal kepada Bank Syariah.

Ini menggambarkan pula sebagai sebuah bentuk ketaatan terhadap prinsipprinsip syariah. Keputusan untuk tetap mempertahankan Bank Syariah berkaitan dengan masalah keimanan dan keyakinan terhadap pengharaman riba bagi umat Islam.

Selanjutnya, hasil studi ini juga menunjukkan bahwa persepsi bagi hasil

berpengaruh positif dan signifikan terhadap minat menabung di Bank Syariah oleh mahasiswa Surabaya. Terbukti dari nilai t hitung lebih besar dari t tabel yakni 3,348>1.9869 dan nilai signifikansi 0,000 <0,05.

Nilai koefisien determinasi berganda (adjusted $R$-square) adalah 0,548 atau $54,8 \%$ nilai ini menunjukkan bahwa $54,8 \%$ berpengaruh positif terhadap minat menabung di Bank Syariah oleh mahasiswa Surabaya. Studi ini juga sesuai dengan penelitian yang dilakukan oleh Rahmawaty (2014) bahwa persepsi bagi hasil berpengaruh positif dan signifikan terhadap minat menabung di Bank Syariah. Hasil studi ini menyatakan bahwa persepsi bagi hasil benar bahwa secara teori berpengaruh positif dan signifikan terhadap minat menabung di Bank Syariah.

Hal ini mengindikasikan gambaran persepsi mahasiswa Surabaya bahwa sistem bagi hasil ini sesuai dengan prinsip-prinsip syari'ah, lebih menguntungkan, dan telah memenuhi rasa keadilan bagi semua pihak. Khususnya dalam bentuk pembagian laba.

Pengaruh persepsi bagi keyakinan dan bagi hasil terhadap minat menabung di Bank Syariah oleh mahasiswa Surabaya, sebagai hasil studi yang ketiga, ini menunjukan bahwa persepsi keyakinan dan bagi hasil secara bersama-sama berpengaruh positif dan signifikan terhadap minat menabung.

Hal ini dapat di buktikan dengan nilai $F$ hitung simultan yang lebih besar dari F table, 56,226>0,05. Nilai koefisien determinasi berganda (adjusted $R$-square) adalah 0,548 atau $54,8 \%$ nilai ini menunjukan bahwa 54,8\% persepsi keyakinan $\left(\mathrm{X}_{1}\right)$ 
dan bagi hasil $\left(\mathrm{X}_{2}\right)$ secara serentak atau bersama-sama berpengaruh terhadap minat menabung di Bank Syariah (Y).

\section{KESIMPULAN}

Hasil penelitian ini menunjukkan bahwa terdapat pengaruh positif dan signifikan persepsi keyakinan terhadap minat menabung di bank syariah di kalangan mahasiswa Surabaya. Persepsi keyakinan akan berpengaruh ketika seseorang merasa bahwa menabung di Bank Syariah adalah tindakan atau perilaku yang erat kaitan dengan halhal yang menyangkut agama dan kepercayaan bahwa riba melanggar hukum Islam. Hal ini diharapkan menjadi strategi Perbankan Syariah dalam meyakinkan nasabah bahwa bunga adalah riba sehingga berhukum terlarang.

Hasil studi menunjukkan bahwa terdapat pengaruh positif dan signifikan persepsi bagi hasil terhadap minat menabung di Bank Syariah pada mahasiswa Surabaya. Persepsi bagi hasil akan berpengaruh ketika seseorang merasa bahwa sistem bagi hasil ini lebih sesuai dengan prinsip-prinsip syari'ah, lebih menguntungkan dan telah memenuhi rasa keadilan bagi semua pihak.

Bank seharusnya meningkatkan kesadaran nasabah termasuk mahasiswa tentang persepsi dan komitmen melalui sosialisasi. Penjelasan tentang sistem bagi hasil di Bank Syariah melalui berbagai media secara berkelanjutan dan tepat sasaran.

Studi ini memberikan informasi bahwa persepsi keyakinan, dan bagi hasil $54,8 \%$ berpengaruh positif terhadap minat menabung di bank syariah oleh mahasiswa Surabaya sedangkan sisanya dijelaskan faktor lain yang tidak diteliti dalam penelitian ini. Untuk itu perlu adanya penelitian lebih lanjut tentang faktor-faktor yang mempengaruhi minat menabung di Bank Syariah.

\section{DAFTAR PUSTAKA}

Abdallah, Muhammad. (2016). Analisis Minat Menabung Pada Bank Syariah di Kalangan Siswa SMA di Kota Medan (Studi Kasus: Siswa Madrasah Aliyah Negeri. Jurnal Ekonomi dan Keuangan. Vol.3 No.7.

Kriyantono, R. (2006). Teknis praktis riset komunikasi. Jakarta: Kencana Prenada Media Group.

Mangani, Ktut Silvanita. (2009). Bank dan Lembaga Keuangan Lain. Jakarta:Erlangga. Rahmawaty, Anita. (2014). Pengaruh Persepsi Tentang Bank Syariah Terhadap Minat Menggunakan Produk di BNI Syariah Semarang. ADDIN. Vol. 8 No. 1, Februari 2014.

Rianto, Nur. (2011). Dasar - Dasar Pembelajaran Perusahaan Edisi 3. Jogjakarta. Sugiyono. (2005). Metode Penelitian Administrasi.Bandung: Alfabeta Jakarta Integrita Press. 
Sumber Mars Indonesia. (2011). Kepemilikan Rekening di Bank Syariah Meningkat. Diunduh dari "http://www.marsindonesia.com/newsletter/ kepemilikanrekening-di-bank-syariah-meningkat. Pada 2 Februari pukul 02.00.

Wibowo, Ery R. (2008). Faktor Relegiusitas dalam Perbankan Syari'ah. Jurnal Ekonomi. Vol. 4 No.1 Semarang. 